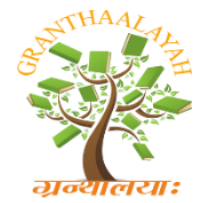

\author{
INTERNATIONAL JOURNAL OF RESEARCH - \\ GRANTHAALAYAH \\ A knowledge Repository
}

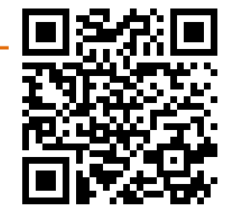

Science

\title{
STUDIES ON INCREASED PLANT POPULATION OF DIFFERENT VARIETIES OF MAIZE (Zea mays L) IN YOLA AND MUBI, ADAMAWA STATE, NIGERIA
}

\author{
Mamudu Njodi ${ }^{1}$, Mohammed D. Toungos ${ }^{2}$, Mu'azu Babayola ${ }^{3}$, Hassan Kashim ${ }^{4}$ \\ ${ }^{1}$ Department of Agric Technology, College of Agriculture Ganye, Adamawa State, Nigeria \\ ${ }^{2,3}$ Crop Science Department, Adamawa State University Mubi. Adamawa State of Nigeria \\ ${ }^{4}$ National Museum Gombe, Gombe State Nigeria
}

\begin{abstract}
Field experiment were conducted at Yola and Mubi locations to study the effects of increased plant population of five (5) varieties of maize Viz: SAMMAZ 11, SAMMAZ 14, SAMMAZ 15, SAMMAZ 16, and SAMMAZ 17 on yield and yield component during the 2011 cropping season. The experimental design was a split plot design with maize varieties as the main plot treatments, while plant population, $(53,333,63,333,80,000$ and 106,666) as the sub-plot treatments. The treatment were replicated three (3) times. Characters measured included plant height, number of leaves per plant, number of days to $50 \%$ tasseling, number of day to $50 \%$ silking, days to $95 \%$ maturity, number of ear per plant, stem diameter, length of ear, diameter of ear, number of grains per ear, 100 grain weight, number of grains per ear. Yield per plot and total grain yield per hectare. The result of the experiments showed that there was significant difference due to varietal effect in plant height at 3 WAS in Yola and at 7 WAS and 9 WAS in Mubi. Variety also affects days to $50 \%$ tasseling, days to $50 \%$ silking and days to $95 \%$ maturity at both locations. Variety also affects ear length at both locations. Interaction of variety and population affected harvest index in Mubi. Population significantly affected yield per plant, yield per plot, total grain yield per hectare in both locations. Combined analysis result showed highly significant effect due to location on plant height at 3 and 5 WAS and also due to variety. Location also affected number of leaves per plant significantly at $3 \mathrm{WAS}$ and highly significantly at 5, 7,9 and 11 WAS. Varieties affected number of leaves per plant at 5 and 9 WAS and was highly significant at 11 WAS. Location and varieties affected days to $50 \%$ tasseling, days to $50 \%$ silking and days to $95 \%$ maturity, while population only affected days to $50 \%$ silking. Diameter of ear and harvest index was highly significant by location and on number of grains per row. Varieties also showed significant differences in length of ear. Location affected straw weight per plant, while varieties affected yield per plant and yield per plot, weight of 100 grain yield and total grain yield per hectare was also highly significantly affected. Population affected yield per plant, especially the ones in Yola. Straw weight, total grain yield and weight of 100 grain were significantly affected. SAMMAZ 15 which gave a plant population of 106,666 ha-1 is recommended at both locations.
\end{abstract}

Keywords: Varieties; Maize; SAMMAZ; Tasseling; Silking. 
Cite This Article: Mamudu Njodi, Mohammed D. Toungos, Mu'azu Babayola, and Hassan Kashim. (2019). "STUDIES ON INCREASED PLANT POPULATION OF DIFFERENT VARIETIES OF MAIZE (Zea mays L) IN YOLA AND MUBI, ADAMAWA STATE, NIGERIA." International Journal of Research - Granthaalayah, 7(4), 14-36. https://doi.org/10.29121/granthaalayah.v7.i4.2019.931.

\section{Introduction}

Maize (Zea mays L) is one of the most important staple food crops in west and Central Africa. The Savanna of west and central Africa has one of the greatest potential for its major production because of relatively higher incident of solar radiation and lower incident of pest and diseases during the cropping season (Badu - Aproku et al, 2006). In 2008, the world production was 822.7million tones, 53.4million tones for Africa and 7.5 million tones for Nigeria (FAO, 2010). Maize production has expended dramatically in the Northern Guinea Savannah of West African, where it has replaced traditional cereals and serves as both a food and a cash crop. In West Africa, Manyoung et al. (1996) assessed maize as one of the five main crops of the farming systems in 124.7million hectare or $72 \%$ of West Africa. The Northern Guinea Savanna alone took about $92 \%$ of the total area grown to maize in Nigeria. Maize is also widely believed to have the greatest potential among food crops for attaining the technological breakthrough that will improve food production in the region (Kamara and Sanginga, 2001).

Maize is a versatile crop and ranks third following wheat and rice in world production as reported by Food and Agricultural Organization (FAO, 2002). It is a source of food and livelihood for millions of people in many countries of the world. It is produced extensively in Nigeria, where it is consumed roasted, baked, friend, pounded or fermented (Agbato, 2003). In advanced countries, it is an important source of many industrial products such as corn sugar, corn oil, corn flour, starch Syrup, brewer's grit and alcohol (Dutt, 2005). Corn oil is used for salad, soap-making and lubrication. Maize is a major component of livestock feed and it is palatable to poultry, cattle and pigs as it supplies them energy (Iken et al., 2001) the stalk, leaves grain and immature ears are cherished by different species of livestock (Dutt, 2005).

In spite of the increasing relevance and high demand for maize in Nigeria, yield across the country continues to decrease with an average yield of about one (1) tonne ha ${ }^{-1}$ which is the lowest African yield recorded (Fayenisin, 1993) as compared to other maize growing countries like Italy $(9,530$ $\left.\mathrm{Kg} \mathrm{ha}^{-1}\right)$, Canada $\left(6630 \mathrm{kgha}^{-1}\right)$, China $\left(4570 \mathrm{~kg} / \mathrm{ha}^{-1}\right)$ and Argentina producing average maize of $560 \mathrm{~kg} / \mathrm{ha}^{-1}$ (Tahir et al., 2009).

There are a number of biotic and abiotic factors that affects maize yield considerably; however, it is more affected by variation in plant density than other number of gross family (Vega et al, 2001). Growing maize at appropriate spacing is one of the bases for higher yield, whereas intra-row spacing at sub. Optimum is a major constrain to attaining the yield potential of the crop (Alofe $e t$ al., 1988) intra-row spacing for maximum grain yield in maize varies from 20 to $45 \mathrm{~cm}$ (Olson and Sanders, 1988). There is no single recommendation for all environments and all maize types and varieties because optimum spacing for optimum maize yield could vary depending on climatic factors such factors as soil fertility, variety and type, planting date and planting pattern among others (Luis, 2001). The intra-row spacing used by local formers for open-pollination extra-early 
maize was found to be the same as for hybrid, medium and late maturing varieties. Thus could be reasons for the low yield obtained by farmers (Ekmo, 1997).

In the present era, the practice of planting maize crop on narrow -row spacing is gaining popularity, particularly among the farmers who know the role of plant population in enhancement of maize yield. Some advantages of reducing plant spacing include the more efficient use of environmental resources, better weed control and higher grain yield particularly maize hybrids that tolerate higher plant density than hybrids used in the past (Duvick and Cassaman 1999; Tollenarr and Lee. 2002; and Sangio et al., 2002). Yield of maize increases with higher plant population up to an optimum number, beyond which it decreases (Tianu et al., 1983). Thus maximum yield can only be obtained by having the optimum plant population density per hectare. Maize maximum economic grain yield is obtained from 30,000 to over 90,000 plants per hectare depending on water availability, fertility, maturity rating, planting date and row spacing (Olson and Sanders 1988). Some factors that contribute to steady decline in maize yield in Nigeria include the rapid reduction in soil fertility caused by intensive use of land and reduction of fallow period as reported by Directorate of Information and Publications of Agriculture (DIPA, 2006), failure to identify and plant high yielding varieties most suited or adapted to each agro-ecological zone (Kim, 1997), and use of in appropriate plant spacing which determine plant population and final yield (Zeidan et al., 2006).

Population is an important agronomic attribute since it is believed to have effects on light interception during which photosynthesis takes place which is the energy manufacturing medium using green parts of the plant. Also it affects the photosphere and rhizhosphere exploitation by the plant especially when spacing gives the right plant density or population which is the number of plant allowed on a given unit area of land for optimum yield (Obi 1991). Moreover, the effect of rapid population growth and the enormous expansion of industrial and other socio economic activities brought about by modernization in the recent years which has resulted in reduction of cultivable land resource as a result of competitive demand for land by the non - agricultural sectors of the economy calls for the need to study and come up with techniques and strategies to increase the yield of crops per unit area so as to maximize and use our little available land more economically.

This experiment was therefore designed with the following objectives:

1) to determine the effect of high plant population on growth, yield components and yield of maize;

2) to determine the effect of variety on growth, yield components and yield of maize;

3) to study the interaction between plant population and variety on the growth, yield components and yield of maize and

4) to determine the optimum plant population for optimum grain yield of the different varieties of maize.

\section{Effect of Plant Population on Growth, Yield Components and Yield of Maize}

Plant population affect most growth parameters of maize even under optimal growth conditions and therefore it is considered a major factor determining the degree of competition between plant (Sangakkara et al., 2004). Increased plant population could lead to increase yields under optimal climatic and management conditions due to greater numbers of smaller cobs per unit area (Bavec 
and Bavec, 2002). Porter et al., (1997) reported that the maximum corn grain yield was recorded at 82,000 to 89,000 plants ha ${ }^{-1}$ and decreasing raw spacing from 0.76 to $0.51 \mathrm{~m}$ resulted in $4 \%$ more grain yield. Bavec and Bavec (2002). Reported increase plant population from 4.5 to 13.5 plants $/ \mathrm{m}^{-}$ 2 significantly changed the following cob characteristic, weight of 1,000 kernels, cob length, number of kernel rows and number of kernels per row. Narrowing row spacing increases light interception by the crop, particularly in the early growing season, there by leading to increased crop growth rates and earlier canopy closure Dally (2004). Ear length decreased with increasing plant density (Kemuel et al., 1983). Singh and Srivastava (1991) reported that decreasing plant density increased the number of grains $\mathrm{cob}^{-1}$. Tianu et al. (1983) reported that 1000 grain weight decreased with increasing plant density. Narayanaswamy et al. (1994) reported higher grain yield was obtained at higher plant population density. Reports of Al-Rudha and Al-Youmis (1998) that maize sown at $15 \mathrm{~cm}$ had maximum plant height compared with their counterparts sown at wider intra-row spacing. Maize plant sown on $15 \mathrm{~cm}$ spacing had higher number of leaves than their counterparts which were sown at wider spacing possibly because of increased growth rate in search for space, sunlight and other environmental resources. (Al - Rudha and Al- Youmis 1998) and Ali et al. (2003). Sharma and Adamu (1984) reported that number of cobs, weight of cobs and grain weight per cob were highest at lower plant population. Al-Rudh and Al-Youmis (1978) reported that maximum thousand grain weight was recorded at wider row spacing while minimum value was recorded at lower plant spacing. Cox and Crasta (1993) reported that plant density recommendations for more modern maize hybrids have increased.

\section{Effect of Variety on Growth, Yield Components and Yield of Maize}

Dingkulu et al, (1991) reports that the longer a crop is able to grow in the particular site in a season, the greater is its biomass production in that site. Thus, increase in Biomass production with longer duration growth reflects, not only the opportunity for more prolonged interception of photosynthetical active radiation by the crop, but also the greater opportunity for uptake of nitrogen and other nutrients especially in low input conditions (Yoshida, 1993). The yield of a crop is a function of a number of factors and process such as high intercepted by the canopy, metabolic efficiency of plant, translocation efficiency of photosynthates from leaves to economic parts and sink capacity or sink strength amongst other (Doku 1977) and the genetic makeup of the crops. Maximum crop production can be achieved by development of improved crop varieties and suitable growing environment and soil with optimum plant population ha ${ }^{-1}$ (Trenton et al., 2006). Maize cultivars had significant difference in days to $50 \%$ silking and tasslling as a result of difference in genetic makeup of these varieties (Hassan 1987). Difference in growth indices of crop varieties have been attributed to differences in genetic characteristic of the individual varieties ( Ibrahim et al., 2000) it was also observed by Dalley et al. (2006) in their experiment that maize sown at narrow space showed increased growth rates as compared with their counterparts sown at wider intra-row spacing probably due to earlier canopy closure for increased light interception as well as increased availability of soil moisture because of equidistance distribution of crop plants.

\section{Effect of Interaction between Plant Population and Variety on Growth, Yield Components and Yield of Maize}

Interaction between varieties and plant population had significantly affected biological yield of maize (Khan et al., 1993) Stover yield was significantly affected by plant population, varieties and their interaction where 65,000 plants ha ${ }^{-1}$ gave the highest while 45,000 plants ha ${ }^{-1}$ gave the lowest 
with Sarhad white variety (Plensicar \& Kustori, 2005). Interaction between Sarhad white maize variety with higher plant density produced higher harvest index as compared to lowest plant population (Park et al., 1989).

Ali.; et al. (2003) reported that competition between maize plants for light, soil fertility and other environmental factors were markedly increased with highest population but decrease with lower plant population and type of variety Sajjan et al. (2002) reported that growth characters of crops varied because of differences in their genetic make - up maize plant sown on $15 \mathrm{~cm}$ spacing had higher number of leaves than the counterpart which were sown at wider spacing possible because of increased growth rate in search for space, sunlight and other environmental resources. Gwized K. (1989) attributed the differences between the leaf area and other growth characters of maize genotypes to difference in photosynthetic activity of leaves, leaf arrangement, chlorophyll contents, stomatal conductance value and activity of photosynthetic enzymes.

\section{Materials and Methods}

Experimental Sites: A Field experiment was conducted at two locations during the 2011 cropping season. One at the Teaching and Research Farm of the Department of Crop Production and Horticulture, Modibbo Adama University of Technology (MAUTECH), Yola and the other one at the former College of Agriculture Teaching and Research Farm Mubi. Yola is located in Northern Guinea Savanna Zone at latitude $9^{\circ} 14^{\prime}$ 'North and longitude 12 $38^{\prime}$ East and altitude of $158 \mathrm{~m}$ above sea level (Kowal and Knabe, 1972) and Mubi is located in Northern Guinea Savanna Zone at latitude $10^{\circ} 3^{\prime}$ North and Longitude $13^{\circ} 07^{\prime}$ East and altitude of 400 meters above sea level (Adebayo and Tukur, 1999). Yola has an annual average minimum and maximum temperatures of $20.2^{\circ} \mathrm{C}$ and $43.5^{\circ} \mathrm{C}^{\prime}$. respectively (AD, ADP, 2001), while Mubi has $24.1^{\circ} \mathrm{C}$ ' and $34.2^{\circ} \mathrm{C}^{\prime}$ minimum and maximum temperatures respectively (AD, ADP, 2001). Maximum rainfall in Yola is around August $\left(292.8 \mathrm{~mm} / \mathrm{mouth}^{-1}\right)$ while Mubi, maximum rain fall is also around (August (440.2 $\mathrm{mm} / \mathrm{month}^{-1}$ ) and minimum is $103.3 \mathrm{~mm} / \mathrm{month}^{-1}$ around October (AD, ADP 2001). The textural class of soils in the two sites is clay loam.

Land Preparation: The fields at both the experimental sites (Mubi and Yola) were ploughed with tractor using disc plough. Hand hoe was used to further clear the remaining weeds and debris out of the farm and also to break down big lumps of soils in order to get good leveling flat land.

Treatments and Experimental Design: The treatments for both experimental sites consist of five maize varieties (SAMMAZ 11, SAMMAZ 14, SAMMAZ 15, SAMMAZ 16 and SAMMAZ 17) which were obtained from Institute for Agricultural Research (IAR) Ahmadu Bello University (ABU) Zaria and are all late maturing (mature in more than 90days) and four plant populations $\left(53,333,63,333,80,000\right.$ and 106,666 plants/ha $\left.{ }^{-1}\right)$ were laid out in a split-plot design. The maize varieties were assigned to the main plots and the plant populations to the sub-plots. These treatments were replicated 3 times. The inter-row spacing however remained at $75 \mathrm{~cm}$ and two plants per hill were maintained till maturity. The total experimental area for the 3 replication was $1,024 \mathrm{~m}^{2}$ (64 m x $16 \mathrm{~m}$ ) which comprised of 60 sub-plots with a net area of $12.0 \mathrm{~m}^{2}$ (4 m x $\left.3 \mathrm{~m}\right)$. Each main plot and replicates were separated by 1 and $2 \mathrm{~m}$ respectively. 
Agronomic Practices: After ploughing and levelling of the experimental areas, the field was marked out according to the design. Maize seeds to be sown were treated with seed dressing chemical Apron Plus at the rate of $50 \mathrm{~g}$ to $6 \mathrm{~kg}$ of seed in order to protect it from soil borne diseases and pest. When the rains were fully established, the seed were sown at Mubi location on $18^{\text {th }} \mathrm{July}$ 2011 while that of Yola location was on $24^{\text {th }}$ July 2011. Three (3) seeds were sown per hole and later thinned to two (2) plants per stand at two weeks after sowing. Weeding was done manually at 3, 6 and 9 weeks after sowing using hand hoe. Fertilizers were applied at the rates of 120:80:80, 160; 80;80, 180:80:80: and 240:80:80kg NPK per hectare for the 53,333, 63,333, 80,000 and 106,666 plants/ha ${ }^{-1}$ respectively. All the phosphorus and potassium fertilizers required were applied at planting while the nitrogen required was split into two, half at planting and the remaining half was further splits into 3 equal doses (at 3, 6 and 8 weeks after sowing) using urea as the source of nitrogen.

Data were collected on the following Characters in both locations (Yola and Mubi).

Plant height: Plant height was measured from the soil surface to the last flag leaf at 3, 5, 7, 9 and 11 weeks after sowing (WAS). Ten plants from the two middle rows were used for the measurement using a graduated $(\mathrm{cm})$ meter ruler. The mean of the ten plants was calculated and recorded as plant height $(\mathrm{cm})$.

Number of leaves per plant: Ten (10) plants, from the two middle rows were randomly selected and the average number of their leaves were used as the number of leaves per plant at 3, 5, 7, 9 and 11 weeks after sowing. Tagging was done to take care of senescence.

Number of days to $50 \%$ tasseling: The number of days from sowing to when $50 \%$ of the plants on a plot tasseled were recorded as the number of days to $50 \%$ tasseling.

Number of days to 50\% silking: The number of day taken by half of the plants to silk in each plot were recorded and regarded as number of days to $50 \%$ silking.

Number of days to $95 \%$ maturity: The number of days it took $95 \%$ of the ears of the maize plant to reach maturity from sowing date in each plot was recorded and regarded as number of days to $95 \%$ maturity.

Diameter of ear: Ten (10) unshelled maize ears from each plot were measured using Vernier caliper. The mean of the ten measured ears was recorded as diameter of ear $(\mathrm{cm})$.

Length of ear: Ten maize ears from the middle two rows of each plot were selected and their length measured using graduated rule. Mean of the ten measured length of ears were recorded as length of ear $(\mathrm{cm})$.

Number of rows per ear: Ten maize ears were selected from each plot and their number of rows counted. The mean numbers of rows on the ten selected maize ears from each plot were recorded as number of rows per ear. 
Number of grains per ear: Mean number of grains per ear from ten selected maize ears from each plot were counted and the mean recorded as number of grain per ear.

Stover yield per plant: After ear harvest, ten plants were randomly selected from each plot and weighed. The mean average of the ten plants was taken as Stover yield per plant $(\mathrm{g})$.

Number of ear per plant: The number of ears from ten (10) randomly selected maize plants from each plot was counted and the mean recorded as number of ears per plant.

Weight of 100 grains: The weight of 100 grains from each plot was determined using Triple Beam Balance 700/800 series by Ohans

Grain yield per plant: The ear from the ten selected maize plant from each plot were shelled and weighed using Triple Beam Balance.700/800 series by Ohans in the laboratory and the mean weight recorded as grain yield per plant.

Grain yield per plot: Dried maize ears were shelled manually and yield was recorded on per plot basis in order to get grain yield per plot.

Grain yield per hectare: Grain yield per hectare for each plot was computed as follows?

$$
\frac{\text { Grain yield per plot }(\mathrm{kg})}{\text { Net plot size }(\mathrm{m} 2)} \times 10,000 \mathrm{~m}^{2}
$$

\section{Harvest index:}

Harvest index for each plot was computed using the formula as follows?

Harvest index $(\mathrm{HI}) \quad \frac{\text { mean grain in weight per plant }(\mathrm{g})}{\text { Mean weight of grain per plant }+ \text { Stover yield per plant }(\mathrm{g})}$

Statistical Analysis: Data collected were analyzed statistically using the generalized linear mode (GLM) procedure of SAS (statistical analysis system v6. 12, 1994). Means that were statistically different were separated using least significant difference (LSD) at $\mathrm{p}<0.05$.

\section{Results and Discussions}

Plant Height: Plant height was not significantly affected by population, variety or location during all the sampling stages except at 3 and 5 (WAS) where variety and location affect plant height. This might be due to the ability of the varieties to compete equally well. It agrees with the work of Saberali (2007) who reported that, with even distribution of resources like rainfall, uniform growth rate is enhanced. Number of leaves was also affected by varieties at later stages of growth towards maturity at both location. However, location also affects number of leaves. This shows that varieties expresses themselves differently towards maturity and also respond differently at different locations. This is related to the work of Al-hudh and Al-youmis (1998) and Ali et al (2003) who reported that maize sown on $15 \mathrm{~cm}$ spacing had higher number of leaves than their counterpart which were sown at wider spacing possibly because of increase growth rate in search 
for space, sunlight and other environmental resources. Maize plant height at 3, 5, 7,9 and 11 weeks after sowing (WAS) as affected by variety and population in Yola is shown in Table 1. There was no significant difference in plant height due to variety, population or their interaction in all the stages measured except at 5 WAS when plant height was significantly affected by variety. SAMMAZ 17 gave the highest plant height $(23.20 \mathrm{~cm})$ followed by SAMMAZ $14(20.06 \mathrm{~cm})$ and the least was SAMMAZ 16 with $15.51 \mathrm{~cm}$. In Mubi highly significant difference in plant height due to variety was observed at 3 and 5 WAS (Table 2). The varietal performance at 3 WAS showed that SAMMAZ 15 gave the highest plant height $(15.23 \mathrm{~cm})$ followed by SAMMAZ $11(14.83 \mathrm{~cm})$ and the least was SAMMAZ $16(12.71 \mathrm{~cm})$. At 5 WAS, SAMMAZ 17 gave the highest plant height $(29.35 \mathrm{~cm})$ followed by SAMMAZ 11. $(27.19 \mathrm{~cm})$ and the least was SAMMAZ 16 $(22.91 \mathrm{~cm})$ as showing on (Table 2)

Table 1: Plant Height $(\mathrm{cm})$ and Ear Height $(\mathrm{cm})$ of Maize Varieties at Different Plant Populations in Yola. In 2011 Rainy Season

\begin{tabular}{|c|c|c|c|c|c|c|}
\hline \multirow[t]{2}{*}{ Treatments } & \multicolumn{5}{|c|}{ Week after sowing } & \multirow[t]{2}{*}{ Ear height } \\
\hline & 3 & 5 & 7 & 9 & 11 & \\
\hline \multicolumn{7}{|l|}{ Varieties (V) } \\
\hline SAMMAZ 11 & 8.45 & 18.81 & 56.18 & 113.78 & 123.40 & 56.98 \\
\hline SAMMAZ 14 & 8.68 & 20.06 & 64.63 & 115.68 & 102.51 & 55.32 \\
\hline SAMMAZ 15 & 7.90 & 17.46 & 47.80 & 99.15 & 105.98 & 49.90 \\
\hline SAMMAZ 16 & 7.35 & 15.51 & 51.20 & 108.10 & 113.01 & 52.22 \\
\hline SAMMAZ 17 & 9.51 & 23.30 & 40.40 & 121.03 & 123.65 & 60.41 \\
\hline Mean & 8.38 & 19.03 & 52.04 & 111.55 & 113.7 & 54.90 \\
\hline $\mathrm{P}<\mathrm{F}$ & $0.110 \mathrm{NS}$ & $0.041^{*}$ & $0.20 \mathrm{NS}$ & $0.059 \mathrm{NS}$ & $0.162 \mathrm{NS}$ & $0.151 \mathrm{NS}$ \\
\hline LSD & 1.639 & 5.032 & 10.01 & 15.105 & 21.14 & 8.764 \\
\hline \multicolumn{7}{|c|}{ Population (Plant $/ \mathrm{ha}^{-1}$ ) } \\
\hline 53,333 & 8.14 & 18.77 & 59.14 & 113.06 & 119.44 & 52.28 \\
\hline 63,333 & 8.10 & 18.11 & 58.74 & 117.76 & 119.76 & 54.76 \\
\hline 80,000 & 9.41 & 21.73 & 64.96 & 114.76 & 117.76 & 55.82 \\
\hline 106,666 & 7.86 & 17.51 & 49.12 & 100.61 & 104.27 & 57.03 \\
\hline Mean & 8.38 & 19.03 & 59.99 & 111.55 & 115.30 & 54.9 \\
\hline $\mathrm{P}<\mathrm{F}$ & $0.153 \mathrm{NS}$ & $0.252 \mathrm{NS}$ & $0.245 \mathrm{NS}$ & $0.069 \mathrm{NS}$ & $0.283 \mathrm{NS}$ & $0.655 \mathrm{NS}$ \\
\hline LSD & 1.466 & 4.501 & 8.50 & 13.51 & 18.00 & 7.83 \\
\hline Interaction $(\mathrm{VxP})$ & NS & NS & NS & NS & NS & NS \\
\hline
\end{tabular}

$\mathrm{NS}=$ not significant at $\mathrm{P}=0.05$

$*$ significant at $\mathrm{P}=0.05$

Table 2: Plant Height $(\mathrm{cm})$ and Ear Height $(\mathrm{cm})$ of Maize Varieties at Different Plant Populations in Mubi in 2011 Rainy Season.

\begin{tabular}{|l|c|c|c|c|c|c|}
\hline \multicolumn{1}{|c|}{ Treatments } & \multicolumn{5}{c|}{ Week after sowing } & Ear height \\
\hline & $\mathbf{3}$ & $\mathbf{5}$ & $\mathbf{7}$ & $\mathbf{9}$ & $\mathbf{1 1}$ & \\
\hline Varieties (V) & & & & & & \\
\hline SAMMAZ 11 & 14.83 & 23.35 & 47.61 & 119.53 & 123.58 & 57.10 \\
\hline SAMMAZ 14 & 14.71 & 25.69 & 47.75 & 114.60 & 119.23 & 60.01 \\
\hline SAMMAZ 15 & 15.23 & 27.19 & 51.17 & 119.98 & 124.70 & 56.86 \\
\hline
\end{tabular}


DOI: 10.5281/zenodo.2653098

\begin{tabular}{|l|l|l|l|l|l|l|}
\hline SAMMAZ 16 & 12.71 & 22.91 & 47.45 & 117.19 & 120.92 & 56.73 \\
\hline SAMMAZ 17 & 14.79 & 29.35 & 53.12 & 114.65 & 126.90 & 58.50 \\
\hline Mean & 14.45 & 26.16 & 49.42 & 117.19 & 132.06 & 57.83 \\
\hline P<F & $0.009 * *$ & $0.01^{* *}$ & $0.803 \mathrm{NS}$ & $0.96 \mathrm{NS}$ & $0.556 \mathrm{NS}$ & $0.681 \mathrm{NS}$ \\
\hline LSD & 1.43 & 3.60 & 11.60 & 17.19 & 14.03 & 5.29 \\
\hline Population (Plant/ha ${ }^{-1}$ ) & & & & & & \\
\hline 53,333 & 14.42 & 25.34 & 47.44 & 116.92 & 119.44 & 59.77 \\
\hline 63,333 & 14.51 & 26.04 & 47.20 & 114.28 & 119.76 & 58.35 \\
\hline 80,000 & 14.16 & 26.67 & 50.06 & 118.36 & 117.76 & 57.02 \\
\hline 106,666 & 14.74 & 26.35 & 53.03 & 122.53 & 104.27 & 56.20 \\
\hline Mean & 14.45 & 26.10 & 49.42 & 118.02 & 115.30 & 57.83 \\
\hline P<F & $0.837 N S$ & $0.638 N S$ & $0.85 N S$ & $0.74 N S$ & $0.283 N S$ & $0.453 \mathrm{NS}$ \\
\hline LSD & 1.28 & 5.22 & 10.38 & 15.37 & 13.45 & 4.73 \\
\hline Interaction (VxP) & NS & NS & NS & NS & NS & NS \\
\hline
\end{tabular}

$\mathrm{NS}=$ not significant at $\mathrm{P}=0.05$

$*$ = significant at $\mathrm{P}=0.05$

$* *$ highly significant at $\mathrm{P}=0.01$

Result from the combined analysis shows that location and variety had highly significant effect on plant height at 3 and 5 WAS (Table 3). Mubi location gave the highest plant height at $3 \mathrm{WAS}$ $(14.45 \mathrm{~cm})$ and also at $5 \mathrm{WAS}(26.10 \mathrm{~cm})$ as against Yola location which have $8.38 \mathrm{~cm}$ at $3 \mathrm{WAS}$ and $19.03 \mathrm{~cm}$ at $5 \mathrm{WAS}$. Varietal effects shows that SAMMAZ 17 had the tallest plants $(12.15 \mathrm{~cm})$ At 3 WAS followed by SAMMAZ $14(11.70 \mathrm{~cm}$ and the least value of $10.04 \mathrm{~cm}$ came from SAMMAZ 16. At 5 WAS, SAMMAZ 17 also recorded the tallest plants with $26.32 \mathrm{~cm}$ followed by SAMMAZ $14(22.87 \mathrm{~cm})$ and the shortest plants $(19.21 \mathrm{~cm})$ were recorded from SAMMAZ 16.

Table 3: Maize Plant Height $(\mathrm{cm})$ and Ear Height $(\mathrm{cm})$ as Affected by Location, Variety and Population in the Combined Analysis in 2011 Rainy Season.

\begin{tabular}{|l|l|l|l|l|l|l|}
\hline \multicolumn{1}{|c|}{ Treatments } & \multicolumn{5}{c|}{ Week after sowing } & Ear height \\
\hline & \multicolumn{1}{|c|}{$\mathbf{3}$} & \multicolumn{1}{|c|}{$\mathbf{7}$} & \multicolumn{1}{c|}{$\mathbf{9}$} & \multicolumn{1}{c|}{$\mathbf{1 1}$} & \\
\hline Location (L) & & & & & & \\
\hline Yola & 8.38 & 19.03 & 70.49 & 111.55 & 113.71 & 54.97 \\
\hline Mubi & 14.45 & 26.10 & 49.42 & 118.02 & 112.25 & 57.83 \\
\hline Mean & 11.42 & 22.56 & 59.95 & 114.78 & 117.9 & 56.40 \\
\hline P<F & $0.0001^{* *}$ & $0.0001^{* *}$ & $0.151 \mathrm{NS}$ & $0.098 \mathrm{NS}$ & $0.051 \mathrm{NS}$ & $0.104 \mathrm{NS}$ \\
\hline LSD & 0.695 & 1.958 & 28.93 & 7.718 & 8.56 & 3.469 \\
\hline Varieties (V) & & & & & & \\
\hline SAMMAZ 11 & 11.64 & 22.08 & 51.89 & 116.65 & 123.45 & 57.04 \\
\hline SAMMAZ 14 & 11.70 & 22.87 & 65.19 & 117.22 & 108.76 & 57.66 \\
\hline SAMMAZ 15 & 11.57 & 22.32 & 49.48 & 109.56 & 115.34 & 53.38 \\
\hline SAMMAZ 16 & 10.04 & 19.21 & 49.32 & 112.64 & 116.94 & 54.47 \\
\hline SAMMAZ 17 & 12.15 & 26.32 & 92.88 & 117.84 & 125.27 & 59.45 \\
\hline Mean & 11.42 & 22.56 & 59.95 & 114.78 & 117.9 & 56.40 \\
\hline P<F & $0.003^{* *}$ & $0.0008^{* *}$ & $0.27 \mathrm{NS}$ & $0.612 \mathrm{NS}$ & $0.117 \mathrm{NS}$ & $0.184 \mathrm{NS}$ \\
\hline
\end{tabular}


DOI: 10.5281/zenodo.2653098

\begin{tabular}{|c|c|c|c|c|c|c|}
\hline LSD & 1.099 & 3.097 & 45.75 & 12.19 & 13.55 & 5.48 \\
\hline \multicolumn{7}{|c|}{ Population (Plant ha ${ }^{-1}$ ) } \\
\hline 53,333 & 11.28 & 22.06 & 52.29 & 114.99 & 120.32 & 56.02 \\
\hline 63,333 & 11.30 & 22.07 & 52.95 & 116.02 & 114.62 & 56.55 \\
\hline 80,000 & 11.38 & 24.20 & 82.51 & 116.56 & 121.36 & 56.42 \\
\hline 106,666 & 11.30 & 21.93 & 51.07 & 111.57 & 115.56 & 56.61 \\
\hline Mean & 11.42 & 22.56 & 59.95 & 114.78 & 117.90 & 56.40 \\
\hline $\mathrm{P}<\mathrm{F}$ & $0.691 \mathrm{NS}$ & $0.30 \mathrm{NS}$ & $0.36 \mathrm{NS}$ & $0.801 \mathrm{NS}$ & $0.608 \mathrm{NS}$ & $0.995 \mathrm{NS}$ \\
\hline LSD & 0.983 & 2.777 & 40.91 & 10.90 & 12.11 & 4.906 \\
\hline Interaction $(\mathrm{VxP})$ & NS & NS & NS & NS & NS & NS \\
\hline
\end{tabular}

$\mathrm{NS}=$ not significant at $\mathrm{P}=0.05$

$*$ significant at $\mathrm{P}=0.05$

$* *$ highly Significant at $\mathrm{P}=0.01$

Number of Leaves: In Yola, there were no significantly differences in number of leaves per plant at 3, 5, 7 and 9 WAS except at 11 WAS where there was highly significance difference among the varieties. (Table 4). SAMMAZ 16 had the highest number of leaves per plant (9.63) followed by SAMMAZ 11(9.05) and the least is SAMMAZ 15 having 8.14 at 11 WAS (Table 4).

In Mubi, except at 9 WAS where significant effects on number of leaves per plant due to varieties where observed, at all other sampling stages, there were no significance difference among varieties populations and their interaction on number of leaves per plant (Table 4).

Results from combined analysis showed that, highly significant differences existed between the two locations on the number of leaves per plant at 3, 5, 7,9 and 11 WAS. At all the sampling times, there were more number of leaves per plant in Mubi than observed in Yola (Table 6).

Significant varietal effect on number of leaves per plant were observed at 5, and 9 WAS and highly significant difference at 11 WAS. SAMMAZ 17 had highest number of leavers per plant at 5 and 9 WAS while SAMMAZ 16 was the highest at 11 WAS.

Table 4: Number of Leave per Plant of Maize Varieties at 3, 5, 7, 9 and 11 WAS on Location, Varieties and Population during 2011 Rainy Season.

\begin{tabular}{|l|l|l|l|l|l|}
\hline \multicolumn{1}{|c|}{ Treatments } & \multicolumn{5}{c|}{ Weeks after sowing } \\
\hline Location (L) & \multicolumn{1}{|c|}{$\mathbf{3}$} & \multicolumn{1}{c|}{$\mathbf{7}$} & $\mathbf{9}$ & \multicolumn{1}{c|}{$\mathbf{1 1}$} \\
\hline Yola & & & & & \\
\hline Mubi & 2.81 & 5.69 & 8.45 & 9.53 & 8.80 \\
\hline Mean & 3.07 & 6.32 & 9.52 & 11.41 & 10.35 \\
\hline P<F & 2.94 & 6.02 & 8.98 & 10.47 & 9.08 \\
\hline LSD & $0.010^{*}$ & $0.0001^{* *}$ & $0.0001^{* *}$ & $0.0001^{* *}$ & $0.0001^{*}$ \\
\hline Varieties (V) & 0.2008 & 0.326 & 0.313 & 0.312 & 0.269 \\
\hline SAMMAZ 11 & & & & & \\
\hline SAMMAZ 14 & 2.85 & 5.71 & 8.82 & 10.45 & 9.61 \\
\hline SAMMAZ 15 & 2.95 & 5.99 & 9.10 & 10.42 & 9.54 \\
\hline SAMMAZ 16 & 2.92 & 5.93 & 8.73 & 10.16 & 9.15 \\
\hline
\end{tabular}




\begin{tabular}{|c|c|c|c|c|c|}
\hline SAMMAZ 17 & 3.16 & 6.56 & 9.38 & 10.70 & 9.63 \\
\hline Mean & 2.94 & 6.02 & 8.98 & 10.47 & 9.58 \\
\hline $\mathrm{P}<\mathrm{F}$ & $0.255 \mathrm{NS}$ & $0.019 *$ & $0.07 \mathrm{NS}$ & $0.024 *$ & $0.009^{* *}$ \\
\hline LSD & 3.317 & 0.516 & 0.495 & 0.493 & 0.426 \\
\hline \multicolumn{6}{|c|}{ Population $\left(\right.$ Plant $\left./ \mathrm{ha}^{-1}\right)$} \\
\hline 53,333 & 2.90 & 5.96 & 8.95 & 10.33 & 9.46 \\
\hline 63,333 & 2.98 & 6.17 & 9.11 & 10.78 & 9.72 \\
\hline 80,000 & 3.03 & 6.03 & 9.07 & 10.49 & 9.62 \\
\hline 106,666 & 2.85 & 5.92 & 8.81 & 10.27 & 9.50 \\
\hline Mean & 2.94 & 6.02 & 8.98 & 10.47 & 9.85 \\
\hline $\mathrm{P}<\mathrm{F}$ & $0.61 \mathrm{NS}$ & $0.699 \mathrm{NS}$ & $0.538 \mathrm{NS}$ & $0.10 \mathrm{NS}$ & $0.516 \mathrm{NS}$ \\
\hline LSD & 0.284 & 0.462 & 0.443 & 0.441 & 0.381 \\
\hline Interaction $(\mathrm{VxP})$ & NS & NS & NS & NS & NS \\
\hline
\end{tabular}

$\mathrm{NS}=$ not significant at $\mathrm{P}=0.05$

$*$ = significant at $\mathrm{P}=0.05$

$* *=$ highly Significant at $\mathrm{P}=0.01$

\section{Phenological Traits}

Days to 50\% tasseling: Days to 50\% tasseling was significantly affected by varieties in both locations. This showed that varieties responds differently at different location due to their different genetic makeup. Combined result also indicates similar trend. Population did not affects days to 50\% tasseling significantly. This is in line with the reports by Hassan. (1987) who reported that maize cultivator had significant difference in days to $50 \%$ tasseling as a result of differences in genetic method of these varieties. Days To 50\% Silking: Data on number of days to 50\% silking showed similar results to that of number of days to $50 \%$ tasseling. This can be supported by similar result from Hassan (1987). Who reported difference in days to 50\% silking as a result of differences in this genetic methods of this varieties.

There were highly significant difference in the number of days to $50 \%$ tasseling due to varieties while population and the interaction between variety and population had no significant effect, on the number of days to $50 \%$ tasseling in Yola (Table 5). Mean performance of varieties showed that SAMMAZ 11 and 16 recorded higher number of days to 50\% tasseling (63 days) each followed by SAMMAZ 17 (60 days) while the least was SAMMAZ 14 (57 days) in Yola.

Table 5: Days to 50\% Tasseling, days to 50\% Silking and Days to 95\% Maturity of Maize Varieties at Different Population in Yola in 2011 Rainy Season.

\begin{tabular}{|l|l|l|l|}
\hline \multicolumn{1}{|c|}{ Treatments } & $\begin{array}{c}\text { Days to } \\
\text { 50\% tasseling }\end{array}$ & $\begin{array}{c}\text { Days to } \\
\text { 50\% silking }\end{array}$ & $\begin{array}{c}\text { Days to } \\
\text { 95\% maturity }\end{array}$ \\
\hline Varieties (V) & & & \\
\hline SAMMAZ 11 & 63 & 67 & 90 \\
\hline SAMMAZ 14 & 57 & 61 & 87 \\
\hline SAMMAZ 15 & 62 & 66 & 90 \\
\hline SAMMAZ 16 & 63 & 67 & 88 \\
\hline SAMMAZ 17 & 60 & 64 & 90 \\
\hline Mean & 61 & 64 & 89 \\
\hline
\end{tabular}




\begin{tabular}{|l|l|l|l|}
\hline $\mathrm{P}<\mathrm{F}$ & $0.002 * *$ & $0.001 * *$ & $0.007 * *$ \\
\hline LSD & 3.024 & 2.866 & 1.968 \\
\hline Population (Plant ha ${ }^{-1}$ ) & & & \\
\hline 53,333 & 61 & 66 & 89 \\
\hline 63,333 & 62 & 66 & 89 \\
\hline 80,000 & 60 & 64 & 89 \\
\hline 106,666 & 60 & 64 & 89 \\
\hline Mean & 61 & 64 & 78 \\
\hline P<F & $0.319 \mathrm{NS}$ & $0.231 \mathrm{NS}$ & $0.961 \mathrm{NS}$ \\
\hline LSD & 2.705 & 2.56 & 1.960 \\
\hline Interaction $(\mathrm{VxP})$ & $\mathrm{NS}$ & $\mathrm{NS}$ & $\mathrm{NS}$ \\
\hline
\end{tabular}

$\mathrm{NS}=$ not significant at $\mathrm{P}=0.05$

$* *$ = Highly significant at $\mathrm{P}=0.01$

In Mubi, similar trends was observed with a highly significant effect due to variety and nonsignificant effect as a result of either population or interaction on number of days to $50 \%$ tasseling. Mean performance of varieties shows that SAMMAZ 16 had the highest number (67 days) followed by SAMMAZ 11, 15 and 17 having 64days each and the least value was recorded from SAMMAZ 16 with 63 days (Table 6).

Result from the combined analysis indicates highly significant effects on number of day to 50\% tasseling as a result of location where Mubi produce the highest number ( 64 days) as against Yola location which had 61 days (Table 7 ).

Variety also affects days to 50\% tasseling significantly. SAMMAZ 16 seen to produce the highest number of days to $50 \%$ tasseling in both locations (65 days) followed by SAMMAZ 11 and 15 having 63 days each and the least value of 60 days was obtained from SAMMAZ 14 (Table 6). There were no significant effect on days to $50 \%$ tasseling as a result of population and interaction between location and population, location and variety, variety and population and location, variety and population.

Days to 50\% silking: In Yola Mean performance of varieties shows that SAMMAZ 11 and SAMMAZ 16 had the highest number of days to 50\% silking (67 days) followed by SAMMAZ 15 with 66 days and the least is SAMMAZ 14 having 61 days.

In Mubi, the same trend also follows with only the varieties showing significant difference in number of days to $50 \%$ silking. The means performance indicates that SAMMAZ 16 had the highest number of days to 50\% silking (72 days). Then followed by SAMMAZ 11 and 15 having 70 days each and the least is SAMMAZ 17 with 69 days.

Table 6: Days to 50\% Tasseling, days to 50\% Silking and Days to 95\% Maturity of Maize Varieties at Different Population in Mubi During 2011 Rainy Season.

\begin{tabular}{|l|l|l|l|}
\hline \multicolumn{1}{|c|}{ Treatments } & $\begin{array}{c}\text { Days to } \\
\mathbf{5 0 \%} \text { Tasseling }\end{array}$ & $\begin{array}{c}\text { Days to } \\
\mathbf{5 0 \%} \text { Silking }\end{array}$ & $\begin{array}{c}\text { Days to } \\
\text { 95\% Maturity }\end{array}$ \\
\hline Varieties (V) & & & \\
\hline SAMMAZ 11 & 64 & 70 & 92 \\
\hline
\end{tabular}




\begin{tabular}{|l|l|l|l|}
\hline SAMMAZ 14 & 63 & 69 & 90 \\
\hline SAMMAZ 15 & 64 & 70 & 92 \\
\hline SAMMAZ 16 & 67 & 72 & 90 \\
\hline SAMMAZ 17 & 67 & 69 & 92 \\
\hline Mean & 64 & 70 & 91 \\
\hline P<F & $0.0007^{* *}$ & $0.0005^{* *}$ & $0.088 \mathrm{NS}$ \\
\hline LSD & 1.84 & 1.47 & 1.76 \\
\hline Population $\left(\right.$ Plant/ha $\left.^{-1}\right)$ & & & \\
\hline 53,333 & 64 & 70 & 91 \\
\hline 63,333 & 65 & 71 & 92 \\
\hline 80,000 & 64 & 69 & 91 \\
\hline 106,666 & 64 & 70 & 91 \\
\hline Mean & 64 & 70 & 91 \\
\hline P<F & $0.584 N S$ & $0.151 \mathrm{NS}$ & $0.67 \mathrm{NS}$ \\
\hline LSD & 1.64 & 1.317 & 1.58 \\
\hline Interaction $(\mathrm{V} x \mathrm{P})$ & $\mathrm{NS}$ & $\mathrm{NS}$ & $\mathrm{NS}$ \\
\hline
\end{tabular}

NS $=$ Not significant at $\mathrm{P}=0.05$

$* *$ Highly significant at $\mathrm{P}=0.01$

Table 7: Combined Days to 50\% Tasseling, Days to 50\% Silking and Days to 95\% maturity of Maize Varieties at Different Population in Yola and Mubi during 2011 Rainy Season.

\begin{tabular}{|l|l|l|l|}
\hline \multicolumn{1}{|c|}{ Treatments } & $\begin{array}{c}\text { Days to } \\
\text { 50\% Tasseling }\end{array}$ & $\begin{array}{c}\text { Days to } \\
\text { 50\% Silking }\end{array}$ & $\begin{array}{c}\text { Days to } \\
\text { 95\% Maturity }\end{array}$ \\
\hline Location (L) & & & \\
\hline Yola & 61 & 65 & 89 \\
\hline Mubi & 64 & 70 & 91 \\
\hline Mean & 63 & 67 & 90 \\
\hline P<F & $0.0001^{* *}$ & $0.001^{* *}$ & $0.0001^{* *}$ \\
\hline LSD & 1.123 & 1.008 & 0.825 \\
\hline Varieties (V) & & & \\
\hline SAMMAZ 11 & 63 & 68 & 91 \\
\hline SAMMAZ 14 & 60 & 65 & 89 \\
\hline SAMMAZ 15 & 63 & 68 & 91 \\
\hline SAMMAZ 16 & 65 & 69 & 89 \\
\hline SAMMAZ 17 & 62 & 67 & 91 \\
\hline Mean & 63 & 67 & 90 \\
\hline P<F & $0.0001 * *$ & $0.0001^{* *}$ & $0.002^{* *}$ \\
\hline LSD & 1.77 & 1.59 & 1.305 \\
\hline Population (Plant/ha $\left.{ }^{-1}\right)$ & & & \\
\hline 53,333 & 63 & 68 & 90 \\
\hline 63,333 & 63 & 68 & 91 \\
\hline 80,000 & 62 & 66 & 90 \\
\hline 106,666 & 62 & 66 & 90 \\
\hline Mean & 63 & 67 & 90 \\
\hline P<F & $0.186 \mathrm{NS}$ & $0.047^{*}$ & $0.717 \mathrm{NS}$ \\
\hline & & & \\
\hline & & & \\
\hline & & & \\
\hline
\end{tabular}




\begin{tabular}{|l|l|l|l|}
\hline LSD & 1.588 & 1.426 & 1.167 \\
\hline Interaction (LxP) & $\mathrm{NS}$ & $\mathrm{NS}$ & $\mathrm{NS}$ \\
\hline Interaction (LxV) & $\mathrm{NS}$ & $\mathrm{NS}$ & $\mathrm{NS}$ \\
\hline Interaction (VxP) & $\mathrm{NS}$ & $\mathrm{NS}$ & $\mathrm{NS}$ \\
\hline Interaction $(\mathrm{L} \times \mathrm{V} \times \mathrm{P})$ & $\mathrm{NS}$ & $\mathrm{NS}$ & $\mathrm{NS}$ \\
\hline
\end{tabular}

$\mathrm{NS}=$ not significant at $\mathrm{P}=0.05$

$*$ significant at $\mathrm{P}=0.05$

$* *$ Highly significant at $\mathrm{P}=0.01$

In combined analysis, number of days to $50 \%$ silking followed similar trend to that of tasseling were highly significant effects was observed as a result of location and varieties. In addition, population affects days to $50 \%$ silking significantly. Mubi location produced the highest number of days to $50 \%$ silking (70 day) while Yola location had 65 days. SAMMAZ 16 had the highest number of days to 50\% silking and was closely followed by SAMMAZ 11 and 15 having 68 days each while the least was SAMMAZ 14 which had 65 days. Population of 53,333 plants/ha ${ }^{-1}$ and 63,333 plants $/ \mathrm{ha}^{-1}$ produced the highest number of days to $50 \%$ silking (68 days each) then followed by 80,000 plants $/ \mathrm{ha}^{-1}$ and $106,666 \mathrm{plants} / \mathrm{ha}^{-1}$ having 66days each (Table 7). Interactions has no significant effect on number of days to $50 \%$ silking.

Days to 95\% Maturity: Results from Yola shows that variety affects days to 95\% maturity highly significantly and in Mubi did not. combined analysis showed that location and variety affects number of days to $95 \%$ maturity. This may be as a result of different environmental condition and different genetic constitution of the different varieties. This supports the work of Ibrahim et al (2000).

Varieties shows highly significant difference in the number of days to $95 \%$ maturity, while population and interaction between variety and population had no significant difference on the number of days to $95 \%$ maturity in Yola. Varietal performance in Yola shows that SAMMAZ 11, 15 and 17 shows the highest number of days to 95\% maturity (90 days each) while SAMMAZ 16 followed with 88 days and the least with SAMMAZ 14 which had 87 days.

There was no significant difference due to varieties, population or interaction between variety and population on the number of days to $95 \%$ maturity in Mubi.

Results from the combined analysis shows that location and variety affect days to $95 \%$ maturity highly significantly. Mubi had the highest number of days to 95\% maturity (91 days) then Yola (89 days).

Varietal effects show that SAMMAZ 11, 15 and 17 produced the highest number of day to 95 maturity (91 days) followed by SAMMAZ 11 and 16 having with 89 days each in combined analysis.

Yield Components: Length of Ear (cm): The data showed that only varieties affect length of ear significantly in both locations. This indicates that different varieties show different response to length of ear at different location. This is in conformity with results of Udoh (2005) who reported 
that some hybrids maize varieties have yield advantage over other maize varieties because they possess such special qualities as high yield, high ear length and placement, uniform flowering.

Result of ear length in Yola indicates that there was significant difference among varieties but not population or interaction between varieties and population.

Mean performance of varieties showed that SAMMAZ 11 had the longest ear length $(15.37 \mathrm{~cm})$, this was followed by SAMMAZ 14 while the lowest was recorded by SAMMAZ 16 with $13.87 \mathrm{~cm}$.

\section{Grain Yield}

Grain Yield Per Plant: Grain yield per plant was not affected significantly due to variety, but population showed significantly difference from the two locations. This shows that where ever the locations, these varieties respond to variations in population. This is in line with the work of Trenton et al, (2006) who reported that maximum crop production can be achieve with improved crop varieties, suitable growing environment and optimum plant population.

Significant difference was observed in grain yield per plant due to population while variety and interaction between variety and population did not significantly affect this character in Yola. Population of 63,333 plants $/ \mathrm{ha}^{-1}$ gave the highest grain yield per plant $(63.9 \mathrm{~g})$ followed by 53,333 plants $/ \mathrm{ha}^{-1}$ population which gave $59.3 \mathrm{~g} /$ plant while the least value of $48.5 \mathrm{~g} /$ plant was obtained from the population of 106,666 plant/ha $\mathrm{ha}^{-1}$ at Yola (Table 8).

Result from Mubi location follows the same trend with that of Yola showing significant differences on grain yield per plant the different plant populations while variety and the interaction between variety and population had no significant effect. Mean performance indicates that population of 63,333 plants $/ \mathrm{ha}^{-1}$ had the highest grain yield/plant $(68.17 \mathrm{~g})$. This was closely followed by 53,333 $\mathrm{plant} / \mathrm{ha}^{-1}(62.22 \mathrm{~g})$ and the least is from $106.666 \mathrm{plants} / \mathrm{ha}^{-1}$ (51.68).

Result from combined analysis shows that varieties and population affects grain yield plant ${ }^{-1}$ significantly. Based on varietal performance, SAMMAZ 15 produced the highest grain yield plant $(62.17 \mathrm{~g})$ from both locations followed by SAMMAZ $16(60.62 \mathrm{~g})$ and the least was SAMMAZ 11 with 52.15g (Table 12) plant population of 63,333plants/ha ${ }^{-1}$ produced the highest grain yield per plant $^{-1}(66.06 \mathrm{~g})$ followed by $53,333 \mathrm{plant} / \mathrm{ha}^{-1}(60.77 \mathrm{~g})$ and the least value of $50.10 \mathrm{~g}$ was obtained from the population of 106,666 plants $/ \mathrm{ha}^{-1}$. The interaction between location and population, location and variety, variety and population and location, variety and population had no significant effect on grain yield plant from combined analysis (Table 9)

Grain Yield Per Plot: Data from the two locations on grain yield per plot followed similar trend with that of grain yield per plant where only plant population affects grains yield per plot while varieties and interaction did not show any significant difference. This is also similar with results of Trenton et al, (2006).

Result from Yola shows that grain weight $/$ plot $^{-1}$ was not affected significantly by variety. Population affected weight of grain/plot ${ }^{-1}$ significantly where 106,666 plant/ha ${ }^{-1}$ gave the highest yield $(6.21 \mathrm{~kg})$. followed by 80,000 plants $/ \mathrm{ha}^{-1}(5.12 \mathrm{~kg})$ and the least was from 53,333 plants/ha 
$(3.79 \mathrm{~kg})$ as seen on table 12 . The interaction between variety and population had no significant effect on grain weight/plot ${ }^{-1}$.

Results from Mubi also shows that variety had no significant effect on weight of grain/plot ${ }^{-1}$ while population affects weight yield per plot $^{-1}$ highly significantly where 106,666 plants/ha ${ }^{-1}$ gave the highest grain yield per plot $^{-1}(6.6114 \mathrm{~kg})$ this was followed by 80,000 plant $/ \mathrm{ha}^{-1}(5.1214 \mathrm{~kg})$ and the least was from 53,333 plants/ha $\mathrm{ha}^{-1}(3.97 \mathrm{~kg}$ ). The interaction between variety and population had no significant effect on grain weight $/$ plot $^{-1}$.

From combined analysis, yield/plot ${ }^{-1}$ was not affected by location, but highly significant difference was observed due to variety and population. On variety, SAMMAZ 15 gave the highest grain yield $/ \operatorname{plot}^{-1}(5.56 \mathrm{~kg})$ followed by SAMMAZ 14 with $5.44 \mathrm{~kg}$ and the least was SAMMAZ 11 with $4.54 \mathrm{~kg}$. On population, 106,666 plant ha $^{-1}$ gave the highest grain weight $/ \mathrm{plot}^{-1}$ of $6.41 \mathrm{~kg}$ which was followed by plant population of 80,000 plants ha $^{-1}$ and the least value of $3.88 \mathrm{~kg}$ came from plant population of 53,333 plant $\mathrm{ha}^{-1}$.

Weight of 100 Grains: Result indicate that weight of 100 grain was not affected by variety, population or their interaction which shows that varieties where able to express their grain formation even at high population in Yola. However, at Mubi, weight of 100 grain was affected significantly due to varieties but not due to population or their interactions. This indicates difference in weight of grain across location effect. Combined analysis showed highly significant difference due to variety and population but not affect by location or any of their interaction. This is supported by the work of Udoh (2005) who reported that some hybrid maize varieties have yield advantage over other maize varieties due to special qualities like high yield, disease resistance, early maturity.

In Yola result of weight of 100 grains showed no significant difference either due to variety, population or their interaction between varieties and population (Table 8). Analysis from Mubi indicate significant difference in weight of 100 grain due to varietal effect while population and interaction between variety and population had no significant effect. Mean performance shows that SAMMAZ 17 had the highest weight of 100 grain $(23.68 \mathrm{~g})$ followed by SAMMAZ 15 (20.36 $\mathrm{g}$ ) and the least value of $17.80 \mathrm{~g}$ was obtained from SAMMAZ 11 (Table 9).

Table 8: Mean Performance of Grain Yield Per Plant, Grain Weight Per Plot, Number of Ear Per plant, Grain Yield Per Hectare and Straw Weight on Variety and Population in Yola in 2011

Rainy Season

\begin{tabular}{|l|l|l|l|l|l|l|}
\hline Treatments & $\begin{array}{c}\text { Grain } \\
\text { yield per } \\
\text { plant(g) }\end{array}$ & $\begin{array}{c}\text { Grain yield } \\
\text { per plant(g) }\end{array}$ & $\begin{array}{c}\text { 100 Grain } \\
\text { weight }\end{array}$ & $\begin{array}{c}\text { No. of ear } \\
\text { per plant }\end{array}$ & $\begin{array}{c}\text { Grain yield } \\
\text { per hectare } \\
\text { (kg/ha } \mathbf{- 1})\end{array}$ & $\begin{array}{c}\text { Grain yield } \\
\text { per straw }\end{array}$ \\
\hline Varieties (V) & & & & & & \\
\hline SAMMAZ 11 & 50.4 & 4.39 & 19.87 & 1.00 & 343.14 & 52.0 \\
\hline SAMMAZ 14 & 58.6 & 5.27 & 17.91 & 1.00 & 4398.45 & 4.6 \\
\hline SAMMAZ 15 & 60.2 & 5.38 & 19.97 & 1.00 & 4488.53 & 52.18 \\
\hline SAMMAZ 16 & 58.7 & 5.23 & 18.40 & 1.00 & 43.60 .99 & 47.48 \\
\hline SAMMAZ 17 & 53.4 & 4.75 & 20.38 & 1.00 & 3962.44 & 55.28 \\
\hline Mean & 56.2 & 5.01 & 19.31 & 1.00 & 4128.51 & 50.33 \\
\hline
\end{tabular}


DOI: 10.5281/zenodo.2653098

\begin{tabular}{|l|l|l|l|l|l|l|}
\hline $\mathrm{P}<\mathrm{F}$ & $0.261 \mathrm{NS}$ & $0.128 \mathrm{NS}$ & $0.184 \mathrm{NS}$ & $0.798 \mathrm{NS}$ & $0.0342^{*}$ & $0.09 \mathrm{NS}$ \\
\hline LSD & 10.28 & 0.869 & 2.422 & 0.0262 & 736.25 & 8.207 \\
\hline $\begin{array}{l}\text { Population } \\
\left(\mathrm{Plant}_{\left.\mathrm{ha}^{-1}\right)}\right.\end{array}$ & & & & & & \\
\hline 53,333 & 59.3 & 3.79 & 19.7 & 19.7 & 3164.11 & 57.84 \\
\hline 63,333 & 63.9 & 4.91 & 20.2 & 20.2 & 40.99 .50 & 41.48 \\
\hline 80,000 & 53.2 & 5.12 & 19.3 & 19.3 & 4169.36 & 47.12 \\
\hline 106,666 & 48.5 & 6.21 & 17.9 & 17.9 & 5081.07 & 44.86 \\
\hline Mean & 56.2 & 5.01 & 19.13 & 19.13 & 4128.51 & 50.33 \\
\hline P<F & $0.009^{* *}$ & $0.0001^{* *}$ & $0.202 \mathrm{~ns}$ & $0.202 \mathrm{NS}$ & $0.0001^{* *}$ & $0.005^{* *}$ \\
\hline LSD & 9.914 & 0.777 & 2.166 & 2.166 & 658.52 & 7.341 \\
\hline $\begin{array}{l}\text { Interaction } \\
(\mathrm{VxP})\end{array}$ & $\mathrm{NS}$ & $\mathrm{NS}$ & $\mathrm{NS}$ & $\mathrm{NS}$ & $\mathrm{NS}$ & $\mathrm{NS}$ \\
\hline $\mathrm{NS}$ & & & & & \\
\hline
\end{tabular}

$\mathrm{NS}=$ not significant at $\mathrm{P}=0.05$

$*$ significant at $\mathrm{P}=0.05$

$* *=$ Highly Significant at $\mathrm{P}=0.01$

Table 9: Mean Performance of Grain Yield Per Plant (g), Grain Weight Per Plot $^{-1}(\mathrm{~kg})$, Number of Ear/ plant ${ }^{-1}$, Grain Yield Per Hectare, and Straw Weight on Varieties and Populations In Mubi

\begin{tabular}{|c|c|c|c|c|c|c|}
\hline Treatments & $\begin{array}{c}\text { Grain } \\
\text { yield per } \\
\text { plant }(\mathrm{g})\end{array}$ & $\begin{array}{c}\text { Grain } \\
\text { Weight per } \\
\text { plot (kg) }\end{array}$ & $\begin{array}{l}100 \text { Grain } \\
\text { weight }(g)\end{array}$ & $\begin{array}{l}\text { No. of ear } \\
\text { per plant }\end{array}$ & 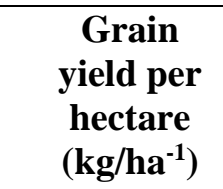 & $\begin{array}{c}\text { Straw } \\
\text { yield per } \\
\text { plant }(\mathrm{g})\end{array}$ \\
\hline \multicolumn{7}{|l|}{ Varieties (V) } \\
\hline SAMMAZ 11 & 53.90 & 4.68 & 17.80 & 1.00 & 3903.04 & 69.43 \\
\hline SAMMAZ 14 & 62.11 & 5.61 & 19.55 & 1.00 & 4617.26 & 71.90 \\
\hline SAMMAZ 15 & 64.15 & 5.74 & 20.36 & 1.00 & 4786.46 & 65.38 \\
\hline SAMMAZ 16 & 62.57 & 5.57 & 19.42 & 1.00 & 4642.55 & 68.10 \\
\hline SAMMAZ 17 & 55.86 & 5.01 & 23.68 & 1.00 & 4164.73 & 65.66 \\
\hline Mean & 59.72 & 5.32 & 20.16 & 1.00 & 4422.81 & 67.70 \\
\hline $\mathrm{P}<\mathrm{F}$ & $0.251 \mathrm{NS}$ & $0.112 \mathrm{NS}$ & $0.011 *$ & $0.272 \mathrm{NS}$ & $0.140 .45 \mathrm{NS}$ & $0.478 \mathrm{NS}$ \\
\hline LSD & 10.95 & 0.917 & 3.22 & 0.063 & 785.45 & 8.72 \\
\hline \multicolumn{7}{|l|}{$\begin{array}{l}\text { Population } \\
\left(\text { Plant } \mathrm{ha}^{-1}\right)\end{array}$} \\
\hline 53,333 & 62.22 & 3.97 & 18.83 & 1 & 3270.40 & 70.56 \\
\hline 63,333 & 68.17 & 5.24 & 22.50 & 1 & 4317.51 & 70.35 \\
\hline 80,000 & 56.80 & 5.47 & 18.61 & 1 & 4580.73 & 67.44 \\
\hline 106,666 & 51.68 & 6.61 & 19.71 & 1 & 5512.59 & 62.51 \\
\hline Mean & 59.72 & 5.32 & 20.16 & 1 & 4422.81 & 62.70 \\
\hline $\mathrm{P}<\mathrm{F}$ & $0.010 *$ & $0.001 * *$ & $0.060 \mathrm{NS}$ & $0.77 \mathrm{NS}$ & $0.0001 * *$ & $0.149 \mathrm{NS}$ \\
\hline LSD & 9.80 & 0.82 & 2.88 & 0.05 & 702.52 & 7.79 \\
\hline $\begin{array}{l}\text { Interaction } \\
(\mathrm{VxP})\end{array}$ & NS & NS & NS & NS & NS & NS \\
\hline
\end{tabular}

$\mathrm{NS}=$ not significant at $\mathrm{P}=0.05$ 
$*$ significant at $\mathrm{P}=0.05$

$* *$ = Highly Significant at $\mathrm{P}=0.01$

Number of ear per plant: Results from both individual location and combined analysis shows that there were no significant difference in number of ear per plant either due to variety, population or interaction between variety and population. (Table 9).

Number of Grains Per Row: Result from combined analysis showed that location affect number of grains per row significantly. This agrees with Sajjan et al, (2002) that crop growth and yield varied because of differences in genetic method of difference crop varieties.

Harvest Index: In Yola significant effect due to variety on harvest index was observed but plant population and interaction between varieties and population had no significant effect. Mubi location showed no significant effect due to varieties, population or interaction between varieties and population. Result from combined analysis showed that location affect harvest index highly significantly. This result is similar to the work of Evans 1993 who reported that Biomass production depends on environmental and agronomic conditions of an area.

Grain yield Per Hectare: In Yola there was significant difference due to varieties and highly significant differences due to population but not significant due to interaction. In Mubi highly significant difference was observed only due to population on grain yield. Combined analysis showed highly significant difference due to varieties and populations on grain yield but no effect due to location or interactions. This is in line with the work of Bavec and Bavec (2002) Marayaswamy et al, (1994) Sharmy and Adamu (1984) Dalley et al., (2006) and Udoh (2005) who all recorded higher yield at higher plant population.

Results from Yola shows that there were significant differences in total grain weight per hectare ${ }^{-1}$ due to varietal effect and highly significant differences due to population. Interaction between variety and population had no significant effect on grain yield $/ \mathrm{ha}^{-1}$. Mean performance of varieties in Yola shows that SAMMAZ 15 gave the highest grain yield $\left(4,488.53 \mathrm{~kg} / \mathrm{ha}^{-1}\right)$ which was closely followed by SAMMAZ $14\left(4,398.45 \mathrm{~kg} / \mathrm{ha}^{-1}\right)$ and the least was recorded from SAMMAZ 11 $\left(3,432.14 \mathrm{~kg} / \mathrm{ha}^{-1}\right)$. Mean performance due to population in Yola shows that 106,666 plants $^{-h^{-1}}$ gave the highest grain yield $\left(5,081.07 \mathrm{~kg} / \mathrm{ha}^{-1}\right)$ followed by 80,000 plants $/ \mathrm{ha}^{-1}(4,169.36 \mathrm{~kg} / \mathrm{ha})$ and

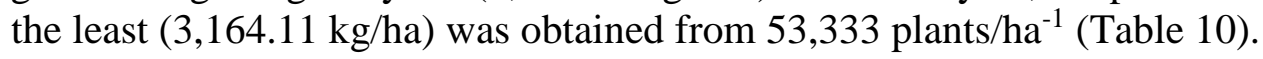

In Mubi location, highly significant difference was observed in grain yield per hectare ${ }^{-1}$ due to population but there were no difference significantly either due to variety or interaction between variety and population. Mean performance on population shows that $106,666 \mathrm{plants} / \mathrm{ha}^{-1} \mathrm{produce}$ the highest grain yield $/ \mathrm{ha}^{-1}\left(5,512.59 \mathrm{~kg} / \mathrm{ha}^{-1}\right)$ followed by $80,000 \mathrm{plants} / \mathrm{ha}^{-1}(4,580.73 \mathrm{~kg} / \mathrm{ha}-1)$ and the least value $(3,270.40 \mathrm{~kg} / \mathrm{ha}$ ) was obtained from 53,333 plants/ha. From combined analysis, grain yield was highly significantly affected by varietal and populations. Varietal performance shows that SAMMAZ 15 produced the highest grain yield $(4,637.50 \mathrm{~kg} / \mathrm{ha})$ followed by SAMMAZ $14(4,507.80 \mathrm{~kg} / \mathrm{ha})$ and the least $(3,667.50 \mathrm{~kg} / \mathrm{ha})$ was recorded from SAMMAZ 11. Performance in terms of population, reveals that 106,666 plants/ha produced the highest grain yield $(5,296.83 \mathrm{~kg} / \mathrm{ha})$ followed by 80,000 plants $/ \mathrm{ha}^{-1}\left(4,375 \mathrm{~kg} / \mathrm{ha}^{-1}\right)$ and least was obtained from 53,333 plants $/ \mathrm{ha}^{-1}\left(321.26 \mathrm{~kg} / \mathrm{ha}^{-1}\right)$. There was no significant effect either due to location or 
interaction between location and population, location and variety, variety and population and location, variety and population.

Straw weight per plant (g): Result from Yola shows that population affects straw weight significantly while variety and interaction between variety and population had no significant effect. Mean performance from population shows that 53,333 plants $/ \mathrm{ha}^{-1}$ had the highest value $(57.84 \mathrm{~g})$, followed by 80,000 plants $/ \mathrm{ha}^{-1}(47.12 \mathrm{~g})$ and the least (41.48 g) came from 63,333 plants/ha ${ }^{-1}$.

Analysis from Mubi location showed that variety, population and the interaction between variety and population had no significant effect.

Combined analysis shows that location and population affects straw weight significant while variety and interaction between location and variety, location and population, variety and population and location, variety and population had no significant effect. Mean performance from combined analysis is shows that Mubi had higher straw weight $(67.70 \mathrm{~g})$ than Yola $(50,33 \mathrm{~g})$ while in terms of population, 53,333 plants $/ \mathrm{ha}^{-1}$ produce the highest straw weight value $(64.17 \mathrm{~g})$ followed by 63,333 plants/ha $\mathrm{ha}^{-1}(60.91 \mathrm{~g})$ and the least value $(53.68 \mathrm{~g})$ was obtained from 106,666 plants $/ \mathrm{ha}^{-1}$..

Table 10: Combined Mean Performance of Yield per Plant (g), Yield per Plot (kg), 100 Grain Weight (g), Number of Ear Per Plant, Total Grain Yield $\left(\mathrm{kg} \mathrm{ha}^{-1}\right)$ and Straw Weight $(\mathrm{g})$ on Location Variety and Population in 2011 Rainy Season

\begin{tabular}{|l|l|l|l|l|l|l|}
\hline Treatments & $\begin{array}{l}\text { Yield per } \\
\text { plant (g) }\end{array}$ & $\begin{array}{l}\text { Yield per } \\
\text { plot (kg) }\end{array}$ & $\begin{array}{c}\text { 100 grain } \\
\text { weight }(\mathbf{g})\end{array}$ & $\begin{array}{c}\text { Number of } \\
\text { ears per } \\
\text { plant }\end{array}$ & $\begin{array}{c}\text { Total grain } \\
\text { yield (kg ha-1) }\end{array}$ & $\begin{array}{c}\text { Straw } \\
\text { Weight (g) }\end{array}$ \\
\hline Varieties (V) & & & & & & \\
\hline Yola & 56.25 & 5.01 & 19.30 & 1.00 & 4128.50 & 50.33 \\
\hline Mubi & 59.72 & 5.32 & 20.16 & 1.00 & 4422.80 & 67.70 \\
\hline Mean & 57.98 & 5.16 & 19.74 & 1.00 & 4422.80 & 59.02 \\
\hline P<F & $0.14 \mathrm{NS}$ & $0.114 \mathrm{NS}$ & $0.18 \mathrm{NS}$ & 0.121 & $0.090 \mathrm{NS}$ & $0.001^{* *}$ \\
\hline LSD & 4.634 & 0.390 & 1.262 & 0.121 & 349.98 & 3.77 \\
\hline Varieties (V) & & & & & & \\
\hline $\begin{array}{l}\text { SAMMAZ } \\
11\end{array}$ & 52.15 & 4.54 & 18.84 & 1.00 & 3667.50 & 60.17 \\
\hline $\begin{array}{l}\text { SAMMAZ } \\
14\end{array}$ & 60.37 & 5.44 & 18.73 & 1.00 & 4507.80 & 58,32 \\
\hline $\begin{array}{l}\text { SAMMAZ } \\
15\end{array}$ & 62.17 & 5.56 & 20.16 & 1.00 & 4637.50 & 58.78 \\
\hline $\begin{array}{l}\text { SAMMAZ } \\
16\end{array}$ & 60.62 & 5.40 & 18.91 & 1.00 & 4501.77 & 57.78 \\
\hline $\begin{array}{l}\text { SAMMAZ } \\
17\end{array}$ & 54.61 & 4.88 & 22.03 & 1.00 & 4063.58 & 60.47 \\
\hline Mean & 57.98 & 5.16 & 19.74 & 1.00 & 4422.80 & 59.02 \\
\hline P<F & $0.031 *$ & $0.005^{* *}$ & $0.005^{* *}$ & $0.157 \mathrm{NS}$ & $0.003 * *$ & $0.674 \mathrm{NS}$ \\
\hline LSD & 7.327 & 0.617 & 1.996 & 0.033 & 553.37 & 5.96 \\
\hline
\end{tabular}




\begin{tabular}{|l|l|l|l|l|l|l|}
\hline $\left.\begin{array}{l}\text { Population } \\
(\text { Plant/ha }\end{array}{ }^{-1}\right)$ & & & & & & \\
\hline 53,333 & 60.77 & 3.88 & 19.77 & 1 & 321.26 & 64.17 \\
\hline 63,333 & 60.06 & 5.07 & 21.35 & 1 & 4213.51 & 60.91 \\
\hline 80,000 & 55.01 & 5.29 & 18.97 & 1 & 4375.04 & 57.28 \\
\hline 106,666 & 50.10 & 6.41 & 18.84 & 1 & 5296.83 & 53.68 \\
\hline Mean & 57.98 & 5.16 & 19.74 & 1 & 4422.80 & 59.02 \\
\hline P<F & $0.0001^{* *}$ & $0.001^{* *}$ & $0.024^{*}$ & $0.461 \mathrm{NS}$ & $0.001^{* *}$ & $0.001^{* *}$ \\
\hline LSD & 6.55 & 0.557 & 1.786 & 0.030 & 494.94 & 5.33 \\
\hline $\begin{array}{l}\text { Interaction } \\
(\text { LxP })\end{array}$ & NS & NS & NS & NS & NS & NS \\
\hline $\begin{array}{l}\text { Interaction } \\
(\text { LxV) }\end{array}$ & NS & NS & NS & NS & NS & NS \\
\hline $\begin{array}{l}\text { Interaction } \\
(\text { VxP) }\end{array}$ & NS & NS & NS & NS & NS & NS \\
\hline $\begin{array}{l}\text { Interaction (L } \\
\text { x V x P) }\end{array}$ & NS & NS & NS & NS & NS & NS \\
\hline NS
\end{tabular}

$\mathrm{NS}=$ not significant at $\mathrm{P}=0.05$

$*$ significant at $\mathrm{P}=0.05$

$* *$ highly significantly at $\mathrm{P}=0.01$

\section{Summary and Conclusion}

A field experiment were conducted at Yola and Mubi locations to study the effects of increased plant population of five (5) varieties of maize Viz SAMMAZ 11, SAMMAZ 14, SAMMAZ 15, SAMMAZ 16, and SAMMAZ 17 on yield and yield component during the 2011 cropping season. The result of the experiments showed that there were significant difference due to varietal effect in plant height at 3 WAS in Yola and at 7 WAS and 9 WAS in Mubi. Variety also affects days to $50 \%$ teasel ling, days to $50 \%$ silking and days to $95 \%$ maturity at both locations. Variety also affects ear length at both locations. Interaction of variety and population affected harvest index in Mubi. Population significantly affected yield per plant, yield per plot, total grain yield per hectare in both locations. Combined analysis result showed highly significant effect due to location on plant height at 3 and 5 WAS and also due to variety highly significantly at 3 and 5 WAS. Location also affected number of leaves per plant significantly at 3WAS and highly significantly at 5, 7, 9 and 11 WAS. Varieties affected number of leaves per plant significantly at 5 and 9 WAS and highly significantly at 11 WAS.

Location and varieties affected days to 50\% tasseling, days to $50 \%$ silking and days to $95 \%$ maturity highly significantly while population only affected days to $50 \%$ silking significantly. Diameter of ear and harvest index was highly significantly affected by location and significantly on number of grains per row. Varieties affected length of ear significantly. Local affected straw weight per plant highly significantly. Varieties affected yield per plant significantly and yield per plot, weight of 100 grain yield, total grain yield per hectare was highly significantly affected. Population affected yield per plant, yield per plot, Straw weight and total grain yield highly significantly and weight of 100 grain significantly. From the experiment, it can be concluded that varieties showed different responses to growth characters at different locations. SAMMAZ 17 
shows higher growth rate early in the season, showed more number of leave per plant at Mubi. SAMMAZ 16 and SAMMAZ 11 showed higher number of days to $50 \%$ tasseling and $50 \%$ silking at both location. SAMMAZ 11 showed higher ear length value at Yola while SAMMA 11 was the highest in Mubi.

It can be concluded that SAMMAZ 15 gave higher values in terms of yield and yield component as compared to other varieties in both locations, with plant population 106,666 plants/ha ${ }^{-1}$ produced the highest grain yield in both locations and is therefore recommended in the two locations.

\section{Competing Interests}

Authors have declared that no competing interests exist.

\section{Authors' Contributions}

This work was carried out in collaboration among all authors. All authors read and approved the final manuscript.

\section{References}

[1] Agbato, S. O. (2003). Principles and practices of Crop production. Odumatt press publisher, Oyo, pp $57-62$.

[2] AD ADP (2001) Adamawa Agricultural Development programme, planning, moniotoring and Evaluation sub-programme.

[3] Al-Rudha, and,m,s and AL.YOUMIS,A.H .(1998) .the effect of rows pacing and nitrogen levels on yield, yield components and quality of maize zea maize L . Iraqi journal of agricultural science ,13;235-252,

[4] Alofe, C. O. Kim, S. K. Efron, Y. Fajemisin, J. M. Khadr, F. H. and Kang, B. T. (1988) Effect of nitrogen and plant density on grain performance of hybrid maize in the forest and derived savanna zone of Nigeria. National Conference on maize Ile-ife Abstract 17pp.

[5] Ali R; Khahil, S. K., Raza, S. M. and Khan, H. (2003) Effects of herbicides and row spacing on maize (Zea mays L) Pakstan Journal of weed science research, 9 (3-4), 171 - 178.

[6] Bavec F. M. Bavec, (2002). Effects of plant populations on leaf area index, cob characteristic and grain yield of early maturing maize cultivars (FAO 100 - 400) European J Agron. 16; 151-159

[7] Badu-Apraku, B., Menkir, A; Fakorede, M. A. B. Fonten Lum, A. and K, Obeng - Antwi (2006) Multivariate analysis of the genetic diversity of fortyseven striga resistant tropical early maturing maize inbred lines. Maydica 51! $551-559$.

[8] Cox W. J. O. R. Crasta, (1993). Grain Silage yield responses of commercial corn hybrids to plant densities p. 132 (in Agronomy abstract As A. Madison W. I.

[9] Dalley, C. D. J. Kells and K. Renner, (2004) Effects of glyphosate application timing and row spacing on corn (Zea May L.) and Soybean (Glycine max) yields weed technol 18:165 - 176.

[10] Dutt, S. (2005). A handbook of Agriculture ABD Publishers, India pp 116 - 118

[11] Duvick, D. N. and K. G. Cassaman (1999). Post green revolution trend in yield potential of temperate maize in the North Central United State, Crop science 39(6); 1622 - 1630

[12] DIPA (2006) Handbook of Agriculture; facts and figures for farmer, students and all interested in farming. Directorate of information and publications of Agriculture Indian Council of Agricultural Research New Delhi, P. 435. 
[13] Ding Kuhu M. H. F. Schnier, S. K. Datta, K Dorffling and C. Jahellana (1991) Relationships between ripening phase productivity and crop production, canopy photosynthesis and senesce in transplanted and direct seeded low land rice field crops Res $26237-345$

[14] Doku, E. V. (1977). Some concept of Crop yield Ghana Journal of Agric. Sci. 10 (1), 53 - 60.

[15] Dallaey, C. D Bernards, M. I. and Kell S. J. J (2006). Effect of weed removal giming and row spacing on soil moisture in corn ( Zea mays L) weed technology, 20:399 - 409

[16] Evans, L. T. (1993) Crop evolution, adaptation and yield. Cambride Univ. Press 500pp

[17] Elemo K. A. (1997) Extra-early maize varieties as affected by the rate and time of N fertilization. Production of regional maize workshop IITA-Cotonou, Benin Republic 419-425

[18] Fayenisin O. (1993), Search for Improved maize varieties for farmers in nigeria $3^{\text {rd }}$ national workshop of maize centre, NASPP, Ibadan December, $6^{\text {th }}-10^{\text {th }}-1976$

[19] FAO (2010). Food and Agriculture Organization of statistics, http//FAOSTAT.wwww.fao.org/faostal Retrieved 2011.

[20] FAO (2002) Fertilizer and the future IFA/FAO Agriculture Conference on global food security and the role of sustainability fertilization. Rome, Italy. $16^{\text {th }}-20^{\text {th }}$ March, 2003, pp 1- 2

[21] Gomez K. A. and A. A. Gomez, (1984) Statistical procedures for agricultural Research $2^{\text {nd }}$ Ed John Willey and Sons, Inc New York 641

[22] Gwizdek, S. (1989). Role of photosynthesis in some maize lines and their hybrids. Hodowla Roslin Aklimaty Zacja nasiennic two, 3 (5-6) $61-72$

[23] Hassan A. E. (1987) Performance of three corn cultivator (Zea mays L) as affected by plant density in Riyada Region J. agric Bio Sci 5: 199 - 203.

[24] Ibrahim, K. Amans A and Abubakar, I. U (2002) Growth indices and yield of tomato ( Lycopes sicon esculentum korest) Varieties as influence by crop spacing at Samaru, proceedings of the $18^{\text {th }}$ HORTSON Conference proceedings (1) $40-47$

[25] Kamuel, M. S. Raouf, M. S. Mahmood, E. A, and S. Amer, (1983). The effect of plant population on local Roumi maize grain yield when grown under irrigation. An Agric Science 19:79 - 93

[26] Khan. A. A. Aziz M. Salim and M. Khan (1993) Response of two maize cultivars to management in puts Sarhad J. Agric, S: 355- 358.

[27] Kamara, A. Y. and Sanginga, N. (2001), Balance nutrient management for intensified maize based systems in the Northern Guinea Savanna of West Africa. In: proceeding of the National Quality Protein Maize Production Workshop $4^{\text {th }}-5^{\text {th }}$ September 2001 at Institute for Agricultural Research Conference Hall. A. B. U. Zaria pp $17-24$.

[28] Kowal, J. M., and D. T. Knabe (1972). An Agroclimatological atlas of Northern Nigeria. Ahmadu Bello University Press, Zaria, Nigeria.

[29] Luis, S. (2001). Understanding plant density effects on maize growth and development. An important issue to maximize grain yield ciencia Rural 3(1); 1-17

[30] Manyong, V. M., Smith, J. Webe, Yagtap, S. S. and Oyewole, B (1996) macro-characterization of Agricultural systems in West Africa; An over view Research and Crop Management Research Monograph No 21. International institute of tropical Agriculture (IITA), Ibadan, Nigeria.

[31] Malges, E., Oliva, N. F. and M. A. Crescimento (1989). Producao de materials seca productive dade da soja suimetida a quator rives de radiacao solar pesgnisa. Agropeenaria Brasiliera, v. a p1073 -1080.

[32] Narayanaswamy, M. R. V. Veerabadran, C. Jayanthi and C. Chinnuswamy, 1994. Planting Density and nutrient management for rainfed maize in red soils madras agricultural J. 81: $248-51$

[33] Olson, R. A and D. H. Sanders (1988). Crop production in corn and corn improvement Madison W. I U. S. A. 686

[34] Obi, U. I. (1991). Maize, its agronomy disease, pest and food values, optional Computer Solutions Limited, Enugu pp207.

[35] Porter, P. D. Hicks, W. Lueschen, J. Ford D. Wames and T. Hoverstad, (1997). corn response to row width and plant population in the northern cornbelt J. prod. Agric., 10:293 - 300. 
[36] Plensicar, M. and R. Kustori (2005) Corn yield and water use as influenced by irrigation level, N rate and planting population. trans, Kansan Acad Sci 53 (4) 121 - 127

[37] Park, S. U, K. Y. Park Y. K. Kang H. J. Moon and S. K Jong (1989). Effect of plant density on growth and yield of sweet corn hybrid Korean J. Crop Sci. 32:92 - 96.

[38] Sangoi, L., Almeida, M. L. Silva, P. R. F. and G. Argenta (2002) Base morfodisiolgrea Pera Major toleca dos hibridos modermos de million a altas desidades de plentes bragantia V. 61p $101-110$

[39] Singh, R. B. and R. K Svivastava, (1991). Response of Maize (Zea mays L) CV kisan Composite of Different planting densities field crop Abstract, 46 910): 6419:1993

[40] SAS (1994) Statistical analysis system sas/stat users guide Version 6, $4^{\text {th }}$ ed, Vol $2-$ SAS institute inc carry N. C USA pp 1675

[41] Saberali S. F. (2007) influence of plant density and planting pattern of corn on its growth and yield under competition with common lambesquarters (Chenopodium album L) Pajouhesh and Sazandegi 74: $143-152$

[42] Sangakkara U. R., P. S. R D. Bandaranayake, J. N Gajanayake and P Stamp (2004). Plant populations and yield of rainfed maize grown in wet and dry seasons of the tropics, maydica 49: $83-88$.

[43] Sharma, T. R. and I. M. Adamu (1984). The effects of plant population on the yield and yield attributing character in maize (Zea mays L.) Zeitschrift far Acker and Pflanzenbau 153(4):315318.field crops Abstract, 38:3437.

[44] Sajjan A. S. Shekhargounda, M. and Badanur (2002). Influence of date of sowing, spacing and levels of nitrogen on yield attribute and seed yield of Okro. Ikamataka Journal of Agricultural Science, 15(2); $267-274$

[45] Tainu, A. I. Picu and M. Tianu, (1983). Influence of sowing density on some physiological elements in Maize yield formation under irrigation problem de-agrofitotehnie Teoretica Si Applicata 5:21930.

[46] Trenton, F. S. Stanger and G L. Joseph (2006) Optimum plant population of bacillus thuringiensis and non-bacillus thuriniensis corn in Wiscoasin Agron J. 98; 914 - 921

[47] Udoh, J. (2005) Crop Production Techniques for the Tropics Concept Publications Limited Munshin, Lagos Nigeria pp $101-106$

[48] Vega C. R. F. H. Andrade and V. O. Sandras (2001) Reproductive partioning and seed set efficiency in Soyabean, Sunflower and maize, Field crop Res. 72: 165 - 173

[49] Yoshida S. (1993). Rice In: IRRI (ed) potential productivity of field crops under different environment. IRRI, Los banos philippiness Substitute

[50] Zeidan, M. S, Amany, A. and Balor El-Kramany M. F. (2006) Effect of N. Fertilizer and plant Density on yield and Quality of maize in Sandy Soil. Research Journal of Agriculture and biological Science 2(4); 156 - 16

\footnotetext{
*Corresponding author.

E-mail address: dahiru.toungos@ gmail.com/toungosm@ adsu.edu.ng
} 